University of Nebraska - Lincoln

DigitalCommons@University of Nebraska-Lincoln

Faculty Publications, College of Journalism \& Journalism and Mass Communications, College Mass Communications

2018

\title{
To Thrive in Today's Marketing Landscape, Embrace Schizophrenia!
}

Rishad Tobaccowala

Directoire + Publicis Groupe, Chicago

Valerie Jones

University of Nebraska - Lincoln, valeriejones@unl.edu

Follow this and additional works at: https://digitalcommons.unl.edu/journalismfacpub

Part of the Broadcast and Video Studies Commons, Communication Technology and New Media Commons, Journalism Studies Commons, Mass Communication Commons, Public Relations and Advertising Commons, and the Social Influence and Political Communication Commons

Tobaccowala, Rishad and Jones, Valerie, "To Thrive in Today's Marketing Landscape, Embrace Schizophrenia!" (2018). Faculty Publications, College of Journalism \& Mass Communications. 118. https://digitalcommons.unl.edu/journalismfacpub/118

This Article is brought to you for free and open access by the Journalism and Mass Communications, College of at DigitalCommons@University of Nebraska - Lincoln. It has been accepted for inclusion in Faculty Publications, College of Journalism \& Mass Communications by an authorized administrator of DigitalCommons@University of Nebraska - Lincoln. 


\title{
To Thrive in Today's Marketing Landscape, Embrace Schizophrenia!
}

\author{
Rishad Tobaccowala $^{1}$ and Valerie K. Jones ${ }^{2}$ \\ 1 Publicis Groupe, Chicago, IL, USA; \\ 2 College of Journalism \& Mass Communications, \\ University of Nebraska-Lincoln, Lincoln, NE, USA \\ Contact - Valerie K. Jones valeriejones@unl.edu College of Journalism \& \\ Mass Communications, University of Nebraska-Lincoln, 341 Andersen Hall, \\ PO Box 880443, Lincoln, NE 68588-0443, USA
}

\begin{abstract}
We are entering the third connected age, powered by deep connections among data, interconnected and Internet-connected objects, and engaging, immersive communication. Communication and media are undergoing radical transformations- influenced by artificial intelligence, the Internet of Things, virtual and augmented reality, and voice-powered devices- and as a result, the advertising landscape is transforming as well. Brands connect directly with consumers, built on rich, data-driven relationships. As the way brands are built changes, so must the skill sets and approaches needed for building and advertising brands. We outline a new model for success and discuss future challenges and opportunities for academics, students, and professionals, to thrive.
\end{abstract}

Published in Journal of Current Issues \& Research in Advertising 2018, vol 39, no 3, pp 266-271.

doi:10.1080/10641734.2018.14973

Copyright (C) 2018 American Academy of Advertising. Published by Routledge/Taylor \& Francis Group. Used by permission. Released under Creative Commons Attribution Non-Commercial license CC-BY-NC. 
Let's start with a riddle. How many advertising dollars

does it take to build a $\$ 420$ million company in 18

months?

Zero, if you're Kylie Jenner.

(Nicolaou and Keane 2018)

This highlights an obvious statement: It's a challenging time to be involved with advertising. This is like saying "the sky is a bit blue"-obvious, and an understatement. Advertising professionals, academics, and students are all scrambling to understand a field that's evolving every day. This article addresses the present state of ad industry issues, future challenges, and how best to prepare current and future talent for success in the dynamic world of marketing communication.

\section{Global trends and ad industry issues}

Before even getting into advertising, let's address the broader context of the environment we're operating within. There are three unstoppable forces requiring that we think and work differently: globalization, demographic shifts, and rapid technological change. We can connect with and promote our products or programs to audiences virtually anywhere in the world. There's a multicultural reality; neat demographic segments that we used to think were important have dissolved, and the future is brown and Buddhist. And technology, which marketing has always been structured around, has exploded. Advertising has always looked the way it did because of the technologies of the time: print, radio, and TV. These were technological breakthroughs in communication. The first connected age, the link, changed that communication structure, giving rise to Google and search engine marketing (post 1993). The second connected age, of mobile and social, enabled connection everywhere, to other people, enabling each of us to become our own media company (post 2007). Now we're experiencing the third connected age, powered by deep connections among data, interconnected and Internet-connected objects, and engaging, immersive communication. This third connected era of artificial intelligence (AI), Internet of Things (IoT), voice, and virtual and augmented reality 
is being ushered in by devices that are faster, run longer, and speak and anticipate, all in a competitive environment that is far more intense and category overlapping than ever before.

All of this plays into the present state of ad industry issues. The single biggest challenge in advertising is that it's built around communication; it's the "fuel supply" for media (Auletta 2018). And communication and media are undergoing revolutionary changes. Skill sets, business models, and the value agencies add to clients are being challenged, at the very same time as clients themselves are being challenged. Traditional brands aren't growing the way that new brands that go directly to the consumer are. Think back to Kylie Jenner and her Kylie Cosmetics company. It's projected to hit $\$ 1$ billion in earnings by 2022 (Strugatz 2017). By contrast, it took 10 years for Estée Lauder Companies Inc.-owned Tom Ford Beauty to earn $\$ 500$ million, 25 years for Bobbi Brown to reach $\$ 1$ billion in earnings, and 80 years for L'Oréal's Lancôme to pass the $\$ 1$ billion mark (Strugatz 2017). Jenner gets to operate on a very different playing field than any of those did. As of company launch in 2016, she had 97.4 million followers on Instagram, 22.8 million followers on Twitter, the most viewed Snapchat account as of August 2016-and products only sold online (Mejia 2017).

The way brands are built is different. The old communication model of how agencies create content and then place it on channels to reach the consumer is no longer required. Brands can connect with global audiences directly. This enables brands themselves to continually collect all first-party data, harvested virtually in real time, from each and every touch point. And data are power. Data are currency. Data are oil. Data fuel every other function of a direct brand's enterprise (Rothenberg 2018). Consider Warby Parker, Uber, Glossier, Away Travel, and Casper. These direct brands are built on data-enriched, data-driven relationships, in which valuable data is extracted from every interaction with the consumer and applied to every touch point and offering, from producing, marketing, and delivering goods and services to the goods and services themselves (Rothenberg 2018).

Add to this the challenge of media brands going direct to consumers as well, without advertising to support them (Netflix, Amazon). Audiences value interruption-free environments because time is valuable. For each of us-our time is valuable. And people are increasingly 
choosing advertising-free environments that don't waste their time. Consumers aren't cows to be milked dry. They are people. They are

gods, really, with god-like power in their pockets. We're advertising to people savvy about media. We can't bombard them into submission, wear them down into finally buying a product. We've been saying this for more than a decade, but how much have we changed the way we practice and teach? The future doesn't fit in the containers of the past - that's true for both the professional and academic advertising industry. As the way brands are built changes, so must the skill sets and approaches needed for building and advertising brands.

\section{Mind-set shift: New model for success}

Brands matter more than ever; they are the ultimate navigation devices in a world of fragmentation. But the way brands are created is different. In the old days you could create a brand by having a well-positioned product, getting big distribution, and putting money behind it in television. But after 2007, almost no brand was created through TV. Instead, direct brands like Airbnb, Warby Parker, Uber, Bonobos, and Dollar Shave Club were created through utilities, services, and experiences, and then advertising was used to grow. Many, many large companies still need television, ad agencies, and the traditional skills they have been trained in. But they also need to think about how they go direct to customers. There are some new skill sets and mind sets that are needed for that. Academics and professionals alike should coach talent in this model, which builds on concepts in Jones \& Tobaccowala (2016).

Start by rethinking who the competition is and what a brand is really "selling," the value it adds. Brands are moving from a share battle, with known competitors, to a growth battle, with unknown competitors. While traditional competitor analyses include other currently existing companies with similar products, goods, or services, competition today may be outside the traditional category, or not in any traditional category at all. Consider how Snap is promoting itself as a camera company, or how Netflix identified its top competitor as sleep (Hern 2017). Even more challenging is that a brand's competitors may not exist yet or may not yet be known. Think of how (relatively) 
quickly Dollar Shave Club emerged-particularly quickly when one considers how far in advance most traditional brands plan their advertising. The real competitor for GM today is Uber, not Ford. That segues into the next shift.

Reconsider the brand offerings to promote, assessing a variety of audiences' wants and needs and thinking beyond "ownership" as the end goal for products. Millennials, for example, care much less about ownership than previous generations. They subscribe to Dollar Shave Club; they call Lyft when they don't have a car. Flexible access-to a car, for example-may still be vital.

Third, in a data- and tech-driven era, move past the idea of segmentation to reaggregation. In the old days, marketers took large audiences and made them small audiences. In the digital world there are audiences of one that can be put together. So, rather than going from a cow to a steak, we're making minced meat into a hamburger. Think of search-engine marketing. This is reaggregation, reaching people who have demonstrated a behavior that reflects interest, rather than segmentation, shouting at broad swaths of demographics in hopes that a portion of them will care.

Amid a skeptical, media-savvy audience, shift focus from marketing to enabling self-marketing. Rather than thinking of "advertising," think of "facilitating." How can brands facilitate excellent experiences and opportunities to easily share those with friends and networks, and reconnect with those friends and networks in the future?

Similarly, in this hyperconnected era of self-marketing, think beyond the traditional idea of packaging a message. No one wants to see "your stupid message" anymore. Interruption-based advertising will decline over the next decade because it's not a good experience for most people (Mandese 2018). The "bombard with a packaged message” model is essentially rooted in disrespecting people's time. So think less about communication and advertising and more about utilities and services. Audiences want their needs to be met, their wants, desires, and goals to be understood and become accessible. The datarich oil that brands collect can be refined, and brands can add value by providing utilities, services, and experiences-that, hopefully, will inspire self-marketing. Think acts, not ads, such as the Nike Fuel Band experience, or the Glade Museum of Feelings. In 2017 Apple launched "Today at Apple," programs at Apple stores around the world in art 
and design, photo and video, music, coding, and more meant to celebrate creativity and connect and inspire participants. "Traditional" advertising becomes a catalyst, a way to ignite interest in and conversations around experiences that add value and earn media.

Finally, channels that used to be regarded separately have now collapsed among one another. We can't neatly separate analog from digital and above the line from below the line. It's also hard to separate awareness, consideration, and traditional stages of purchase decisions because it all happens too quickly. A well-organized marketing platform is like someone has thrown hydrochloric acid on it and it's all spewing together, with connected channels feeding into each other. So it's important to rethink how organizations come together, from how talent is hired to how behavior is incentivized, and what it is organized around.

The single most important thing a business has is the relationship with the customer or consumer. If you were to ask consumers "Do you want to build relationships with brands?" they would most likely say "No." If they have a headache, they just want the headache to go away, not to build a relationship with Tylenol. But if you were to ask them "Do you want detergent sent to you right when you need it? Do you want products and services tailored to you? Do you want help reaching your goal?" their answers would likely be very different. Those things are possible when a relationship is there, and that relationship is built on data and transformed into better goods, products, utilities, services, or experiences for the audience.

\section{Preparing students: Schizophrenia is the way forward}

Whether preparing for a meeting or for a class, in this professional environment we need to be schizophrenic, balancing both today and tomorrow, focusing on both roots and wings. There are some things that will always be needed and will never change: an understanding of the field, what is happening and what has happened. These are roots, and if you don't have these, it's hard to convince audiences to change or think differently. Roots provide credibility. Wings, on the other hand, provide inspiration. They come from new ideas, from helping audiences-students or clients-think creatively and think differently about the future. 
Similarly, marketers must deliver today, and students need skills they can apply today, but they also need to ensure they are prepared for and investing in tomorrow. It's no longer an either-or choice but both at the same time.

More specifically, advertising today requires three bundles of skills and abilities. First, teach people how to communicate and work in teams. That's still important. Help them develop roots by understanding how communication has worked, and by being good at storytelling, and convincing someone of their point of view. In a connected age, collaborating and working in teams, even those you've never met, are vital as well. The second bundle is around content. We all have to regularly upgrade based on this. It's good to know the old avenues, but you have to update the map. Think about new areas such as social influence and selling directly, the importance of which is evidenced by Jenner's Kylie Cosmetics. Show how the field is changing and how to integrate with other disciplines. The third bundle is around teaching people to learn, to think, to teach themselves, because some of the content you teach will stay and some will become obsolete. Help them learn to think analytically and be comfortable with statistics and refining the "oil" that is data, which is increasingly important in advertising. Beyond just the ability to run analysis to get meaning, good thinkers will also be able to listen hard so they can understand what the real problem is and then tell the story to sell their analysis.

\section{Cross-pollination: Professional and academic collaboration}

How do we work together? By sending faculty to the real world and by bringing the real world to faculty. Ensure that someone from industry comes to your program or class every month for at least a day or two. Many of you, no doubt, regularly invite guest lecturers into your classes. Could that be done more strategically, with greater integration into the curriculum and coordination around the visit so that more students benefit? On the flip side of things, academic programs should partner with marketers, agencies, and tech companies and have every professor spend 2 weeks in the real world every 2 years. This can happen through channels such as the Advertising Educational Foundation's Visiting Professor Program or within your own communities. 
How do we integrate and require more current thinking to sprout wings for students, faculty, and professionals? Some universities provide one-credit pop-up courses for students in specialized, topical areas, taught by professors, alumni, or professionals, and open to talent across campus. This is a great way to be interdisciplinary, attract diverse skill sets, and build partnerships with industry. Think about what you can export to or import from other parts of the university. Consider talent in tech or stats who will work in advertising companies and vice versa. Further, think about how your programs can bundle opportunities for professionals who need to upgrade their content and skills.

\section{Future challenges and opportunities}

As “outside” people who aren't making money from persuasion, academics have the benefit of being viewed as neutral and believable. That provides great opportunity to focus on research structured for the benefit of a society that's impacted by what corporations do. Help society and industry by studying the big issues of the future: privacy, trust, and manipulation. How are people are being impacted in a world where we spend all of our time on mobile phones, checking them 150 times per day (Harris 2016)? How can technology take over your mind, and have the opposite effect of empowerment? Teach students about where the field is going, what implications are, and what role advertising should and should not play.

One particular potent challenge in a data-driven environment is considering the line between persuasion and manipulation and mind control. Jaron Lanier, a pioneer in the field of virtual reality and current interdisciplinary scientist at Microsoft, has talked about what went wrong on the Internet, and the repercussions of adopting a model of ad-supported content in which content that gets attention gets rewarded. With the rapid pace of technology, one of the unstoppable forces noted earlier, and more and more data, Lanier worries that "advertising has morphed into continuous behavior modification on a mass basis, with everyone under surveillance by their devices and receiving calculated stimulus to modify them" (Kulwin 2018). A/B testing, for example, shows that the more extreme option beats the less 
extreme. So we live in an environment of extremes, when nuanced thinking is ever more important. Tristan Harris, former Google design ethicist and co-founder of the Center for Humane Technology, argues that much technology is based on intermittent variable rewards, like slot machines; we take out our phones and play the slot machine to see what notifications we get, what social approval we get through social media (Harris 2016). How is the Internet being fueled? What's the impact of content? Are we in the media manipulation business? These questions will shape our future, and you and your students can help answer them.

Ultimately, humans don't like change, but we have to embrace it. We are all still students ourselves. At Publicis, we have reorganized around providing one-to-one consumer engagement at scale, and focused on the importance of three things: data skills to identify and understand audiences; thinking broadly about creativity, which includes ideas, new ways of reaching people and communications; and building everything around the empowered person (consumer) and their journey. This comes down to understanding what the customer is trying to do and where and how best to deliver. There are parallels with redesigning academic programs-we have to deal with different types of client needs, we need to find ways to be more productive (faster and getting done more with less) and we need to remain relevant by building or partnering for new skills.

When thinking about the future, consider the three Cs: competition, cannibalization, and competence. Get a blank sheet of paper, and create a competitor to yourself, bounded only by the rule of law and making money in three years. New organizations can destroy you because they are organized for tomorrow and you are organized for yesterday. Second, consider how to cannibalize yourself. This involves taking money away from old things that worked and funding new things, which no company likes to do. But if you don't cannibalize, someone else will. Third, question your own competence. There's no way to be successful in this professional environment besides continuous education and learning. Spend 1 hour per day or 7 hours per week studying and learning new things; refer to the reference list for some starting points. And embrace schizophrenia, balancing both today and tomorrow as you and your students thrive in today's marketing landscape. 
Disclosure No potential conflict of interest was reported by the authors.

\section{References}

Auletta, Ken. 2018. Fremenies: The Epic Disruption of the Ad Business (and Everything Else). London, UK: Penguin Press.

Harris, Tristin. (2016 May 18). "How Technology is Hijacking Your Mind-from a Magician and Google Design Ethicist," Medium. https://medium.com/thriveglobal/how-technology-hijacks-peoples-minds-from-a-magician-and-google-sdesign-ethicist-56d62ef5edf3

Hern, Alex. (2017 April 18). “Netflix’s Biggest Competitor? Sleep,” The Guardian. https://www.theguardian.com/technology/2017/apr/18/ netflix-competitor-sleep-uber-facebook

Jones, Valerie K, and Rishad Tobaccowala. 2016. "The Future of Advertising: What You Need to Know." In The New Advertising: Branding, Content, and Consumer Relationships in the Data-Driven Social Media Era, edited by Ruth Brown, Valerie K. Jones, and Ming Wang, 375-84. Santa Barbara, CA: Praeger. https:// digitalcommons.unl.edu/journalismfacpub/109/

Kulwin, Noah. (2018 April 17). "One Has This Feeling of Having Contributed to Something That's Gone Very Wrong,” New York Magazine. http://nymag.com/ selectall/2018/04/jaron-lanier-interview-on-what-went-wrong-with-theinternet.html

Mandese, Joe. (2018 February 2). "Publicis' Tobaccowala: Advertising Will Decline 30\% In Next 5 Years," Mediapost. https://www.mediapost.com/publications/ article/313938/publicis-tobaccowala-advertising-will-decline-30.html

Mejia, Zameena. (2017 September 14). "How Kylie Jenner turned her \$29 lipstick business into a $\$ 420$ million empire in 18 months," CNBC. https://www.cnbc. com/2017/og/14/how-kylie-jenner-turned-kylie-cosmetics-into-a-420-millionempire.html

Nicolaou, Anna, and Aimee Keane. (2018 May 6). "Retail: Is the Beauty Industry Amazon-Proof?," Financial Times. https://www.ft.com/content/ acfe1924-4deg-11e8-8a8e-22951a2d8493

Rothenberg, Randall. (2018 June 22). "How to Be a 21st Century Brand." Speech, IAB Annual Leadership Meeting, Palm Desert, CA.

Strugatz, Rachel. (2017 August 9). “Kylie and Kris Jenner Rethink Beauty's Model," WWD. http://wwd.com/beauty-industry-news/beauty-features/ kylie-and-kris-jenner-re-think-beautys-model-10958329/ 